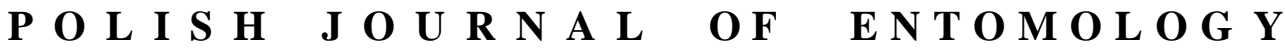

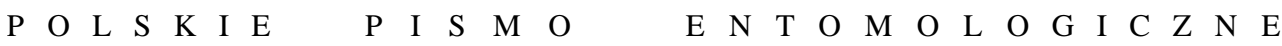

VOL. 85: $237-246$

Lublin

30 June 2016

DOI: $10.1515 /$ pjen-2016-0013

\section{Effect of aqueous extracts of black alder (Alnus glutinosa (LINNAEUS, 1753) GAERTNER, 1791) and elder (Sambucus nigra LiNNAEUS, 1753) on the occurrence of Brevicoryne brassicae LINNAEUS, 1758 (Hemiptera, Aphidoidea), its parasitoid Diaeretiella rapae (M'INTOSH, 1855) (Hymenoptera, Ichneumonoidea) and predatory Syrphidae on white cabbage}

\author{
BEATA JANKOWSKA ${ }^{*}$, ELŻBIETA WOJCIECHOWICZ-ŻYTKO \\ Department of Plant Protection, Faculty of Biotechnology and Horticulture, Kraków \\ University of Agriculture, 29 Listopada 54, 31-425 Kraków, Poland
}

\begin{abstract}
The insecticidal and antifeedant effects of aqueous extracts from two common plants (black alder Alnus glutinosa and elder Sambucus nigra) on the occurrence of Brevicoryne brassicae, its parasitoid Diaeretiella rapae and predatory Syrphidae on white cabbage were investigated in 2008-2009. Both extracts reduced the number of cabbage aphids, although the Sambucus nigra extract proved to have a better effect. Differences were seen both in the numbers of winged aphids settling on plants and in the overall numbers of aphids on plants during the entire season. There were no significant differences in the degree of parasitization by Diaeretiella rapae in the three experimental combinations. Eight species of Syrphidae were found in the Brevicoryne brassicae colonies: Episyrphus balteatus, Sphaerophoria scripta, S. rueppelli, S. menthastri, Eupeodes corollae, Scaeva pyrastri, Scaeva selenitica and Syrphus vitripennis. The dominant species was Episyrphus balteatus. The largest numbers of syrphid larvae and pupae were collected from cabbage aphid colonies on the control plants. Smaller numbers were recorded on the plot where the cabbages were sprayed with the Sambucus nigra extract. The results of this study indicate that botanical insecticides based on S. nigra have the potential to be incorporated into control programmes for the cabbage aphid.
\end{abstract}

KEY WORDS: cabbage aphid, natural enemies, botanical insecticides.

\footnotetext{
* Corresponding author: jankowskab@ogr.ar.krakow.pl
} 


\section{INTRODUCTION}

Commercially, white cabbage is one of the most important vegetables in Poland. Several pests attack cabbage and can cause serious financial losses. The most important pest affecting white cabbage every year is the cabbage aphid Brevicoryne brassicae LINNAEUS, 1753 (JANKOWSKA \& WIECH 2004, SZWEJDA 2004). The parasitoid Diaeretiella rapae (M'INTOSH, 1855) (GABRYŚ \& SOBOTA 1994, JANKOWSKA \& WIECH 2003, DUCHOVSKIENÉ \& RAUDONIS 2008, DUCHOvSKIENĖ et al. 2010) and aphidophagous Syrphidae (WNUK 1971, WNUK \& WOJCIECHOWICZ 1993, JANKOWSKA 2005, 2012) are of the greatest importance in limiting the numbers of this aphid.

The misuse and excessive use of chemical pesticides cause irrevocable harm to natural communities and adversely affect the quality of agricultural products. That is why interest in the possibilities of applying natural substances to protect plants against pests has been growing in recent years. The pesticidal properties of many plants have been known for a long time, and natural pesticides based on plant extracts such as rotenone, nicotine and pyrethrum are commonly used in pest control. Plants may be an alternative to the currently used insect control agents because they are an abundant source of bioactive organic chemicals. Plants contain a number of chemical substances that are not directly beneficial to their growth and development. These secondary compounds act on insects as repellents, antifeedants, toxins; they also have an antibacterial and fungistatic impact (NAWROT 1984, BURGIEŁ 2005). Many authors have made reference to the antifeedant activity of plant extracts in relation to phytophagous insects associated with cabbage (ENDERSBY \& MORGAN 1991). Although biologically active substances such as botanical pesticides impact the target organism, they also have side effects on non-targets, such as natural enemies. These effects are relatively minor, however, and are therefore tolerable.

The aim of this work was to determine the impact of aqueous extracts of two wild plants - black alder (Alnus glutinosa (LinNAEUS, 1753) GAERTNER, 1791) and elder (Sambucus nigra LINNAEUS, 1753) - on the presence of Brevicoryne brassicae, its parasitoid Diaeretiella rapae and predatory Syrphidae.

\section{Funding}

This research was supported by the Ministry of Science and Higher Education of Poland as part of the statutory activities of Department of Plant Protection, University of Agriculture, DS-3500/WBiO/. 


\section{MATERIAL AND METHODS}

The research was carried out at an organic farm in Roczyny near Andrychów (2008) and at the Experimental Station of the Plant Protection Department of the University of Agriculture in Mydlniki near Kraków (2009). The white cabbage cultivars Kamienna Głowa (2008) and Amager (2009) were used in the experiments. In late-May 75 seedlings were transplanted to $12 \mathrm{~m}^{2}$ plots $(6 \mathrm{~m}$ long by $2 \mathrm{~m}$ wide) at a spacing of $40 \times 50 \mathrm{~cm}$. No chemical treatment was applied and weeds were removed mechanically. Three experimental combinations were studied: A - unsprayed cabbage (control), B - cabbage sprayed with Alnus glutinosa extract, $\mathrm{C}$ - cabbage sprayed with Sambucus nigra extract.

Black alder and elder are both locally common and are cheap and easy to obtain. To prepare the extracts, young healthy leaves were harvested from trees growing in their natural habitats and then dried in a ventilated room without access to sunlight. The extracts were made by allowing $50 \mathrm{~g}$ of ground dried leaves to stand in $100 \mathrm{ml}$ water for 24 hours (WAWRZYNIAK 1996), after which the extracts were filtered through muslin. Cabbage plants were sprayed once weekly, in the evenings. Fifteen plants situated in the central part of each plot ( 3 replicates of 5 plants each) were selected and marked. The analyses were carried out once a week, 1-2 days after spraying. Each time the winged and non-winged forms of the cabbage aphid, both living in colonies and solitary, were counted. In order to assess the degree of parasitization mummies in the aphid colonies were counted by direct observation. The number of mummies provides feedback on the activity of parasitoids and their so-called field effectiveness (BARCZAK 1992). In 2009 larvae and pupae of Syrphidae from the aphid colonies from all the plants on the plots were collected and reared. The emerged adults were identified to species level based on the keys by BAŃKOWSKA (1963) and VAN VEEN (2004). Duncan's multiple range test $(\alpha=0.05)$ was used for the statistical analysis of the results.

\section{RESULTS}

Both aqueous extracts affected the occurrence of Brevicoryne brassicae in that fewer cabbage aphids were counted on the extract-treated plants. There were differences both in the numbers of winged aphids settling on plants and in the numbers of aphids on the plants throughout the season (Table 1). The Sambucus nigra extracts proved to be superior in this respect, the deterrent effect of the aqueous extract from Alnus glutinosa being far weaker. During the peak occurrence of aphids, their numbers were twice (2008) and eleven times as high (2009) on the control plants as on the plants sprayed with the Sambucus nigra extract (Table 1). 
Table 1. Occurrence of the cabbage aphid Brevicoryne brassicae (2008-2009); A - unsprayed cabbage (control), B - cabbage sprayed with Alnus glutinosa extract, C - cabbage sprayed with Sambucus nigra extract.

\begin{tabular}{|c|c|c|c|}
\hline \multirow[t]{2}{*}{ Information } & \multicolumn{3}{|c|}{ Combination } \\
\hline & $\mathbf{A}$ & B & $\mathbf{C}$ \\
\hline \multicolumn{4}{|l|}{2008} \\
\hline Mean number of winged aphids per plant & $0.96 \mathrm{~b}$ & $0.85 \mathrm{~b}$ & $0.53 \mathrm{a}$ \\
\hline Time of aphid maximum occurrence & $11 \mathrm{VII}$ & $18 \mathrm{VIII}$ & $18 \mathrm{VIII}$ \\
\hline $\begin{array}{l}\text { Mean number of aphids/plant during the maximum } \\
\text { occurrence }\end{array}$ & $28 \mathrm{c}$ & $19.7 \mathrm{~b}$ & $14 \mathrm{a}$ \\
\hline Mean number of aphids per plant & $1.9 \mathrm{~b}$ & $1.22 \mathrm{a}$ & $1.1 \mathrm{a}$ \\
\hline $\begin{array}{l}\text { Reduction in numbers of aphids depending on the aqueous } \\
\text { extract applied [\%] }\end{array}$ & - & 35.8 & 42.1 \\
\hline Parasitization by Diaeretiella rapae [\%] & $26 \mathrm{a}$ & $25 \mathrm{a}$ & $27.8 \mathrm{a}$ \\
\hline \multicolumn{4}{|l|}{ 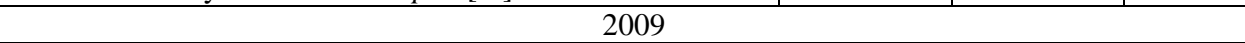 } \\
\hline Mean number of winged aphids per plant & $0.7 \mathrm{c}$ & $0.3 \mathrm{~b}$ & $0.1 \mathrm{a}$ \\
\hline Time of aphid maximum occurrence & 28 VIII & $10 \mathrm{VII}$ & $10 \mathrm{VII}$ \\
\hline $\begin{array}{l}\text { Mean number of aphids/plant during the maximum } \\
\text { occurrence }\end{array}$ & $35 \mathrm{~b}$ & $6 \mathrm{a}$ & $3 \mathrm{a}$ \\
\hline Mean number of aphids per plant & $13.7 \mathrm{~b}$ & $2.3 \mathrm{a}$ & $1.6 \mathrm{a}$ \\
\hline $\begin{array}{l}\text { Reduction in numbers of aphids depending on the aqueous } \\
\text { extract applied [\%] }\end{array}$ & - & 83.2 & 88.2 \\
\hline Parasitization by Diaeretiella rapae $[\%]$ & $36.6 \mathrm{a}$ & $34.2 \mathrm{a}$ & $30.2 \mathrm{a}$ \\
\hline
\end{tabular}

The mean numbers identified in the rows with the same letters do not differ significantly $(\alpha=0.05)$.

In both years the numbers of aphids on the plants were substantially reduced by the parasitoid Diaeretiella rapae. The percentage of parasitization varied between combinations from $2.5 \%$ to $27.8 \%$ in 2008 , and from $30.2 \%$ to $36.6 \%$ in 2009 (Table 1). There were no significant differences in the degree of parasitization in any of the experimental combinations.

Syrphidae whose predatory larvae fed in cabbage aphid colonies were another important factor in reducing the aphid population. A total of 68 syrphid larvae and pupae were collected during the observation period in 2009. The presence of eight hoverfly species was confirmed: Episyrphus balteatus (DE GEER, 1776), Syrphus vitripennis MEIGEN, 1822, Sphaerophoria scripta (LINNAEUS, 1758), S. rueppelli (WIEDEMANN, 1830), S. menthastri (LINNAEUS, 1758), Eupeodes corollae (FABRICIUS, 1794), Scaeva pyrastri (LINNAEUS, 1758 ) and S. selenitica (MEIGEN, 1822).

The species composition and numbers of Syrphidae are listed in Table 2. Episyrphus balteatus was the most abundant syrphid species (eudominant) in all three experimental combinations. The second most numerous species was Eupeodes corollae, but it was absent in the Brevicoryne brassicae colonies on the plot where the cabbages were sprayed with the Sambucus nigra extract. The largest numbers of syrphid larvae and pupae were collected 
from the control plants (Table 2). Smaller numbers were found on the plot where the cabbages were sprayed with the $S$. nigra extract. These differences were significant in relation both to the control and to the plot where the cabbage plants were sprayed with the Alnus glutinosa extract (Table 2).

Aphidophagous Syrphidae are attacked by a wide range of parasitic Hymenoptera (WOJCIECHOWICZ-ŻYTKO 2000, JANKOWSKA 2004). They reduce the number of syrphids and negatively affect their function of controlling aphid populations. Parasitized syrphid larvae were collected only from cabbage aphid colonies feeding on the control plants and on the cabbages sprayed with the Alnus glutinosa extract (Table 2).

Table 2. Species composition and numbers of syrphids in cabbage aphid colonies on white cabbage according to the experimental combination used (2009); A - unsprayed cabbage (control), B - cabbage sprayed with Alnus glutinosa extract, C - cabbage sprayed with Sambucus nigra extract.

\begin{tabular}{|c|c|c|c|c|c|c|c|c|}
\hline \multirow[t]{3}{*}{ Species of Syrphidae } & \multicolumn{6}{|c|}{ Combination } & \multirow{2}{*}{\multicolumn{2}{|c|}{ Total }} \\
\hline & \multicolumn{2}{|c|}{$\mathbf{A}$} & \multicolumn{2}{|c|}{ B } & \multicolumn{2}{|c|}{$\mathrm{C}$} & & \\
\hline & No. & $\%$ & No. & $\%$ & No. & $\%$ & No. & $\%$ \\
\hline Episyrphus balteatus & 19 & 46.4 & 4 & 25 & 10 & 83.34 & 33 & 47.8 \\
\hline Sphaerophoria scripta & 4 & 9.8 & 2 & 12.5 & 1 & 8.33 & 7 & 10.1 \\
\hline S. rueppelli & 3 & 7.3 & 1 & 6.25 & - & - & 4 & 5.8 \\
\hline S. menthastri & 1 & 2.4 & 1 & 6.25 & - & - & 2 & 2.9 \\
\hline Eupeodes corollae & 6 & 14.6 & 2 & 12.5 & - & - & 8 & 11.6 \\
\hline Scaeva pyrastri & 3 & 7.3 & 2 & 12.5 & - & - & 5 & 7.3 \\
\hline S. selenitica & - & - & 1 & 6.25 & - & - & 1 & 1.4 \\
\hline Syrphus vitripennis & 2 & 4.9 & 1 & 6.25 & 1 & 8.33 & 4 & 5.8 \\
\hline Parasitized larvae & 3 & 7.3 & 2 & 12.5 & - & - & 5 & 7.3 \\
\hline Total & $41 \mathrm{c}$ & 100 & $16 \mathrm{~b}$ & 100 & $12 \mathrm{a}$ & 100 & 69 & 100 \\
\hline
\end{tabular}

The mean numbers identified in the rows with the same letters do not differ significantly $(\alpha=0.05)$.

\section{DISCUSSION}

Characteristic plant odours (volatile chemicals) are credited with the major role of guiding phytophagous insects to their host plants (HARBORNE 1997). In the process of host plant finding, glucosinolanes (GS) and some of their breakdown products, e.g. the isothiocyanates (ITC) present in all brassicae plants, are important phagostimulants for the cabbage aphid (ZABŻA 1989, HARBORNE 1997, GABRYŚ 1999). Foraging aphids are attracted by host-plant volatiles and supposedly repelled by volatiles from non-host plants (VISSER et al. 1996). The spraying of cabbage with extracts of plants that are not host plants may mask their proper scent; in relation to the cabbage aphid it may also indicate 
antifeedant activity (ENDERSBY \& MORGAN 1991). Moreover, plant extracts can lead to the mortality of aphids which are already on the plants (ACHREMOWICZ 1995, ACHREMOWICZ \& CIEŻ 1998). Most Sambucus nigra parts, but particularly the leaves, are thought to contain various cyanogenic glycosides and to be somewhat toxic (ATKINSON \& ATKINSON 2002). In Poland research on the usefulness of substances obtained from plants in limiting the number of aphids was carried out by PUSZKAR et al. (1994), ACHREMOWICZ (1995), ACHREMOWICZ \& CIEŻ (1998), BARCZAK (1994), BARCZAK \& GULEWICZ (1998), DANCEWICZ \& GABRYŚ (2008), KSIĘŻAK et al. (2008) and WOJCIECHOWICZ-ŻYTKO et al. (2013). Antifeedant activity in relation to the cabbage aphid was achieved by spraying cabbage with extracts of French marigold (Tagetes patula LinNAEUS, 1753) extract (JANKOWSKA 2008), Calendula officinalis LINNAEUS, 1753. and Euphorbia cyparissias LinNAEUS, 1753 (JANKOWSKA \& WILK 2009), and Calendula sp., Chrysanthemum carinatum SCHOUSBOE, 1800 and Coriandrum sativum LinNAEUS, 1753 (JANKOWSKA 2012).

The parasite Diaeretiella rapae is one of the most important factors reducing numbers of the cabbage aphid (GABRYŚ \& SOBOTA 1994, JANKOWSKA \& WIECH 2003, DUCHOVSKIENE \& RAUdonis 2008, DuChOVSKIENĖ et al. 2010). According to NEMEC \& STARY (1984) and ElLIOT et al. (1994), Diaeretiella rapae prefers Brevicoryne brassicae to other aphids. The degree of parasitization of aphids on white cabbage was found to be $14.2-17-6 \%$ in Poland (JANKOWSKA \& WIECH 2003), 23.9-26.2\% in Lithuania (DUCHOVSKIENEE \& RAUDONIS 2008) and 22.7-26.6\% in England (ChUA 1977).

The same signals that attract herbivorous insects are also attractive to predators and parasitoids (HARAMATHA \& NAWROT 1985). According to many authors Diaeretiella rapae is attracted by allyl isothiocyanate (READ et al. 1970, ZABŻA 1989, TITAYAVAN \& ALTIERI 1990), which is released when cabbage plants are damaged. The coverage of plants with extracts may confuse not only aphids but also parasitoids. Some authors found that the application of plant extracts did not affect the performance of the natural enemies of insect pests (JANKOWSKA 2012); others reported a negative impact of plant extracts on parasitoids (BARCZAK 1994, WYROSTKIEWICZ et al. 1996, JANKOWSKA \& WILK 2009).

The most effective agents controlling the cabbage aphid are hover flies, whose predatory larvae feed in cabbage aphid colonies. All the species found during this research are common, and their significance in limiting numbers of cabbage aphids was confirmed by other authors from Poland (WNUK 1971, WNUK \& WOJCIECHOWICZ 1993, JANKOWSKA 2005, 2012).

KINDLMANN \& RŮŽIČKA (1992) found that syrphid larvae did not feed on parasitized aphids, so their feeding did not limit the effectiveness of the parasite Diaeretiella rapae.

Botanical insecticides are among the best alternatives to synthetic pesticides. Oviposition and feeding deterrent properties are important factors in pest control, and the 
results of this study indicate that botanical insecticides based on Sambucus nigra have the potential to be incorporated into control programmes for the cabbage aphid. Another important aspect regarding the application of botanical insecticide formulations should be their compatibility with other integrated pest management strategies.

\section{CONCLUSIONS}

1. Aqueous extracts of Alnus glutinosa and Sambucus nigra both reduced the number of cabbage aphids, but the effect of the latter extract proved to be superior

2. There were no significant differences in the degree of parasitization by Diaeretiella rapae in the three experimental combinations.

3. Eight species of Syrphidae were found in the Brevicoryne brassicae colonies: Episyrphus balteatus, Sphaerophoria scripta, S. rueppelli, S. menthastri, Eupeodes corollae, Scaeva pyrastri, Scaeva selenitica and Syrphus vitripennis. Episyrphus balteatus was the most abundant syrphid species in all three experimental combinations

4. The largest numbers of syrphid larvae and pupae were collected from cabbage aphid colonies on the unsprayed plants. Smaller numbers were observed on the plot where the cabbages were sprayed with the Sambucus nigra extract.

\section{REFERENCES}

ACHREMOWICZ J. 1995. Research into new aphicides of plant origin. Pestycydy 1995(4): 27-36. (in Polish)

AChremowicz J., CieŻ W., 1998. Tests on the effect of plant extracts applied as aphicides. Zeszyty Problemowe Postępów Nauk Rolniczych 353: 53-66. (in Polish)

AtKInSON M.D., AtKinson E. 2002. Sambucus nigra L. Journal of Ecology 90(5): 895-923.

BaŃKowska R. 1963. Identification keys for the insects of Poland. XXVII Flies - Diptera. Issue 24 Syrphidae. PWN, Warszawa. (in Polish)

BARCZAK T. 1992. Evaluation of the degree of parasitization of the aphid populations (Homoptera, Aphidodea) - a review of methods. Wiadomości Entomologiczne 11(4): 229-234. (in Polish)

BARCZAK T. 1994. Effect of Polygonaceae plant extracts on black bean aphid (Apis fabae SCOP.) and its parasitoids. Zeszyty Problemowe Postępów Nauk Rolniczych 414: 245-252. (in Polish)

BARCZAK T., GULEWICZ K. 1998. Evaluation of the effect of lupin-nicotine preparation on black bean aphid (Aphis fabae Scop.) and its parasitoids (Hymenoptera: Parasitica). Polskie Pismo Entomologiczne 67(1-2): 155-163.

BuRgIEŁ Z. 2005. Can plant preparations replace synthetic pesticides? [in:] K. WIECH, H. KoŁOCZEK, P. KASZYCKI (eds). Ochrona środowiska naturalnego w XXI - nowe wyzwania i zagrożenia. 
Fundacja na Rzecz Wspierania Badań Naukowych Wydziału Ogrodniczego Akademii Rolniczej im. Hugona Kołłataja w Krakowie, Kraków, 116-125. (in Polish)

CHUA T.H. 1977. Population studies of Brevicoryne brassicae (L.), its parasites and hyperparasites in England. Researches on Population Ecology 19(1): 125-139.

DANCEWICZ K., GABRYŚ B. 2008. Effect of extracts of garlic (Allium sativum L.), wormwood (Artemisia absinthium L.) and tansy (Tanacetum vulgare L.) on the behavior of the peach potato aphid Myzus persicae (SUlz.) during the settling on plants. Pesticides 2008(3-4): 93-99.

DuchovskienĖ L., RAudonis L. 2008. Seasonal abundance of Brevicoryne brassicae L. and Diaeretiella rapae (M'INTOSH) under different cabbage growing systems. Ekologija 54(4): 260-264.

Duchovskiené L., Starkute R., TAmošIŪ R. 2010. Abundance of cabbage aphid and their natural enemies in differently fertilized and covered with agro-film white cabbage. Sodininkyste ir daržininkystè 29(4): 59-66.

Elliot N.C., ReED D.K., French B.W., Kindler S.D. 1994. Aphid host effects on the biology of Diaeretiella rapae. Southwestern Entomologist 19(3): 279-283.

ENDERSBY N.M, MoRGAN W.C. 1991. Alternatives to synthetic chemical insecticides for use in crucifer crops. Biological Agriculture and Horticulture 8: 33-52.

GABRYŚ B. 1999. Semiochemicals in the biology and ecology of the cabbage aphid Brevicoryne brassicae L. Zeszyty Naukowe Akademii Rolniczej we Wrocławiu, Rozprawa habilitacyjna $\mathrm{Nr}$ 356: 1-84. (in Polish)

Gabryś B., Sobota G. 1994. Species spectrum, relative abundance and populations dynamics of parasitoids and hyperparasitoids of Brevicoryne brassicae (L.) and Myzus persicae (SuLZ.) (Homoptera, Aphididae) on white mustard (Sinapis alba L.). Aphids and Other Homopterous Insects 4: 33-39.

HaRamata J., NAwROT J. 1985. The plant substances that affect the development and behavior of insects. [in:] Materiały XXV Sesji Naukowej IOR. Instytut Ochrony Roślin, Poznań 141-151. (in Polish)

HARborne J.B. 1997. Biochemical Ecology. PWN, Warszawa. (in Polish)

JANKOWSKA B. 2004. Parasitoids of aphidophagous Syrphidae occurring in cabbage aphid (Brevicoryne brassicae L.) colonies on cabbage vegetables. Journal of Plant Protection Research 44(4): 299-305.

JANKOWSKA B. 2005. Predatory syrphids (Diptera, Syrphidae) occurring in the cabbage Aphid (Brevicoryne brassicae L.) colonies on the different cabbage vegetables. Journal of Plant Protection Research 45(1): 9-16.

JANKOWSKA B. 2008. Effect of French marigold (Tagetes patula nana) plant water extract on the occurrence of pest insects on white cabbage. Progress in Plant Protection 48(2): 724-729. (in Polish)

JANKOWSKA B. 2012. Selected non-chemical methods of cabbage vegetables protection and their impact on harmful and beneficial entomofauna. Zeszyty Naukowe Uniwersytetu Rolniczego w Krakowie, ser. Rozprawy 491(368): 1-131. (in Polish) 
JANKOWSKA B., WIECH K. 2003. Occurrence of Diaeretiella rapae (M'InTOSH) (Aphidiidae) in the cabbage aphid (Brevicoryne brassicae L.) colonies on the different cruciferous crops. Horticulture and Vegetable Growing 22(3): 155-163.

JANKOWSKA B., WIECH K. 2004. The comparison of the occurrence of the cabbage aphid (Brevicoryne brassicae L.) on the cabbage vegetables. Vegetable Crops Research Bulletin 60: 71-80.

JANKowsKa B., WiLK A. 2009. The impact of plant water extracts from Calendula officinalis L. and Euphorbia cyparissias L. on the occurrence of Brevicoryne brassicae LinNEAUS, 1758 (Hemiptera, Aphidoidea) and its parasitoid Diaeretiella rapae (M'INTOSH, 1855) (Hymenoptera, Ichneumonoidea). Aphids and Other Hemipterous Insects 15: 195-204.

Kindlmann P., RůžIČKA, Z. Z. 1992. Possible consequence of a specific interaction between predators and parasite aphids. Ecological Modelling 61(3-4): 253-265.

KsIĘŻAK J., BıAŁY Z., Kot I. 2008. Evaluation of the usability of alfalfa (Medicago spp.) saponins for bean aphid control in faba bean. Progress in Plant Protection 48(3): 903-907. (in Polish)

NAwrot J. 1984. Natural products in the protection of plants. Pestycydy 3(4): 1-31. (in Polish)

NemeC V., Stary P., 1984. Population diversity of Diaeretiella rapae (M'InT.) (Hym., Aphidiidae), a parasitoid in agroecosystems. Zeitschrift für Angewandte Entomologie 97(3): 223-233.

Puszkar L., JastrzęBSKi A., JuRysta M., Bialy Z. 1994. Alfalfa saponins as a chance in the integrated hop protection. [in:] Materiały 34 Sesji IOR, Tom 2. Intytut Ochrony Roślin, Poznań, 255-259. (in Polish)

ReAd D.P., FeenY P.P. Root R.B. 1970. Habitat selection by the aphid parasite Diaeretiella rapae (Hymenoptera: Braconidae) and hyperparasite Charips brassicae (Hymenoptera: Cinipidae). The Canadian Entomologist 102(12): 1567-1578.

SZWEJDA J. 2004. Review of pests and their natural enemies actually occurring on cabbages in Poland. Nowości Warzywnicze 39: 97-102. (in Polish)

Titayavan M, Altieri M.A. 1990. Synomone-mediated interactions between the parasitoid Diaeretiella rapae and Brevicoryne brassicae under field conditions. Entomophaga 35(4): 499-507.

VAN VeEN M.P. 2004. Hoverflies of Northwest Europe. Identification keys to the Syrphidae. KNVV Publishing, Utrecht, The Netherlands.

VISSER J.H., PIRON P.G.M., HARDIE J. 1996. The aphids' peripheral perception of plant volatiles. Entomologia Experimentalis et Appllicata 80(1): 35-38.

WAWRZYNIAK M. 1996. Evaluation of selected plants extract on Large White (Pieris brassicae L., Lepidoptera, Pieridae). Akademia Techniczo-Rolnicza im. Jana i Jędrzeja Śniadeckich w Bydgoszczy, Bydgoszcz. (in Polish)

WNUK A. 1971. Syrphids (Syrphidae, Diptera), predators of cabbage aphid Brevicoryne brassicae (L.) (Aphididae, Homoptera). Zeszyty Naukowe Wyższej Szkoły olnicynej w Krakowie nr 62 Rolnictwo 13: 45-53. (in Polish)

WNuk A., WoJcIECHOwICZ E. 1993. Syrphid predators (Diptera, Syrphidae) occurring in colonies of the cabbage aphid, Brevicoryne brassicae (L.), on cabbage and cauliflower. Polskie Pismo Entomologiczne 62(1-4): 215-229. (in Polish) 
WoJCIECHOwiCZ-ŻYTKo E. 2000. Diplazon laetatorius (Hymenoptera, Ichneumonidae) as a parasitoid of aphidophagous Syrphidae (Diptera). [in:] Proceedings of the $15^{\text {th }}$ Czech and Slovak Plant Protection Conference in Brno, September 12-14, 2000. Research Institute of Crop Production, Prague, 447-448.

Wojciechowicz-Żytko E., Jankowska B., BurgieŁ Z., WiLK E. 2013. The efficacy of water extracts of marigold (Tagetes patula nana L.) and Sosnowski's hogweed (Heracleum sosnowskyi MADEN) in reducing diseases and pests broad beans. Episteme 20(I): 603-612. (in Polish)

Wyrostkiewicz K., Wawrzyniak M., Barczak T., Aniszewski T., Gulewicz K. 1996. An evidence for insecticide activity of some preparations from alkaloid-rich lupin seeds on Colorado potato beetle (Leptinotarsa decemlineata SAY), larvae of the large white butterfly (Pieris brassicae L.), black bean aphid (Aphis fabae SCOP.) and on their parasitoids (Hymenoptera, Parasitica) populations. Bulletin of the Polish Academy of Sciences, Biological Sciences 44(1-2): 29-39.

ZABŻA A., 1989. The chemical bases of plant-insect interactions. Kosmos 36(1), 155-177. (in Polish)

Received: 27 November 2015

Accepted: 15 January 2016 